\title{
THE COMBINATION OF GROWTH HORMONES INCREASED THE IN VITRO SHOOTS MULTIPLICATION ON SAGO PALM (Metroxylon sagu Rottb.)
}

\author{
Kombinasi Hormon Tumbuh Meningkatkan Perbanyakan Tunas In Vitro pada \\ Tanaman Sagu (Metroxylon sagu Rottb.)
}

\author{
Teuku Tajuddin*, Karyanti, Tati Sukarnih, Nadirman Haska \\ Biotech Center BPPT, Building 630 PUSPIPTEK Area, Setu, Tangerang Selatan, Banten 15314 \\ *E-mail: teuku.tajuddin@bppt.go.id
}

\begin{abstract}
ABSTRAK
Pohon sagu (Metroxylon sagu Rottb.) mempunyai banyak keunggulan dibanding dengan tanaman-tanaman penghasil pati lainnya, khususnya karena memiliki produktivitas yang tinggi, tumbuh di area bantaran sungai dan rawa, yang merupakan lingkungan tidak sesuai bagi pertumbuhan tanaman-tanaman lain. Dalam rangka membangun suatu perkebunan sagu di area yang luas, maka sangat dibutuhkan anakan-anakan sagu yang ukurannya seragam dalam jumlah yang besar. Namun demikian, terbatasnya jumlah anakan yang seragam telah menjadi kendala bagi pengembangan perkebunan sagu. Sebagai alternatif, perbanyakan in vitro dengan induksi tunas langsung dilakukan untuk mendapatkan bibit-bibit sagu dengan genotip unggul secara masal. Anakan sagu yang diperoleh dari Propinsi Maluku digunakan sebagai sumber eksplan. Eksplan dikultur pada media MS dan B5 yang mengandung kombinasi hormon auksin dan sitokinin. Hasil penelitian menunjukkan bahwa perlakuan BAP 2.0 ppm dan NAA 2.0 ppm menghasilkan jumlah tunas terbanyak.
\end{abstract}

Kata kunci: Auksin, sitokinin, in vitro, sagu, inisiasi tunas

\begin{abstract}
Sago palm (Metroxylon sagu Rottb.) has many advantages over other starch-producing crops especially for its higher yield, ability to grow along riverbanks and on swampy areas not suitable for other crops. With the purpose of establishing large-scale plantations, a large amount of uniform sago palm suckers are required. However, limited availability of uniform suckers has hindered the mass propagation and development of cultivated Sago palm. Alternatively, in vitro cultures were performed in order to obtain a large-scale of mass clonally propagation of superior genotypes of sago palm. The young suckers obtained from areas of Maluku Province were used as explants. In vitro culture was carried out through direct shooting. The explants were cultured on two kinds of media, which were MS and B5 media containing various growth hormones of auxins and cytokinins. The results showed that the treatment with BAP 2.0 ppm and NAA 2.0 ppm produced the highest number of shoots.
\end{abstract}

Keywords: Auxin, cytokinin, in vitro, sago palm, shoot initiation 


\section{INTRODUCTION}

Sago palm (Metroxylon sagu Rottb.) as one of the Indonesian original plants is growing in almost all islands in Indonesia. However natural sago forest in large area (1.2 million hectares or $90 \%$ ) can be found in Maluku and Papua Provinces (Flach 1997). Sago palm has many advantages over other starch-producing crops especially for its higher yield. The palm grows along riverbanks and in swampy areas which are not suitable for other crops. Sago palm was recognized as the mankind's oldest food plant with the starch contained in the trunk used as a staple food for local people who lives in Southeast Asia (Jong 1995). Its utilization has diversed into various products and materials for industries, such as noodles, snacks, raw materials for beer and glutamate fermentation, and also biodegradable plastics (Okazaki et al. 2005).

There are wide genetic diversities of sago palm found in Maluku and Papua areas. The basis of diversities are on types of sago palm, morphology, starch productivity, chemical content and starch harvesting time (Setyabudi and Widyaningtyas 2008). There are two types of sago palm grown in Sentani area, Papua. These are spiny type (Metroxylon rumphii Martius) and spineless type (Metroxylon sagu Rottbol). The spiny types are varied into several kinds, which are known as local name as Para Habou/Para Hundsai, Rondo, Munggin, Pui, Manno, Eubesung, Ruruna and Yaghalobe. While the spineless types are Yepha Hundsai/Yepha Hembokluw/Yepha Ebung, Osoghulu, Follo, Pane, Wanni, Ninggih, Yukulen, Hopolo, Yakhe, Hilli, Fikhela and Henambo. In Seram Island, Maluku, Tuni and Ihur are recognized as a spiny type; whereas Red Molat and White Molat are a spineless type. From those varieties, there are 6 potential types that could be developed as high carbohydrate resource sago palms in future. These are Osoghulu (spineless type) with the starch production of $207.5 \mathrm{~kg} / \mathrm{tree}$, Eubesung (spiny type) with $207 \mathrm{~kg} /$ tree, Yepha (spineless type) $191.5 \mathrm{~kg} /$ tree, Follo (spineless type) $176 \mathrm{~kg} / \mathrm{tree}$, Wanni (spineless type) $160.5 \mathrm{~kg} / \mathrm{tree}$, and
Yaghalobe (spiny type) $155.5 \mathrm{~kg} /$ tree. Instead of these six types, there is another type which has specific characteristic. The starch content of this type can be eaten directly without any additional processing. The type is known as Rondo (spiny) with the starch production of $127 \mathrm{~kg} /$ tree (Miftahorrachman and Novarianto 2003).

Sago palm is propagated generatively by seed and vegetatively by suckers. Seedlings grow into a rosette stage of leaves, and trunk is only formed after $4-6$ years of planting. Nevertheless, suckers are the most popularly used planting material for establishing sago palms in gardens and plantations. Continuous suckering multiplies the palm, then forming a cluster around the mother palm. With the purpose of establishing large-scale plantations, a large amount of uniform suckers are required. However, limited availability of uniform suckers has hindered the mass propagation and development of cultivated sago palm. One of the vegetative propagation, which is in vitro culture method, is performed in order to avoid above problems, as well as to provide vigor and qualified planting materials. In vitro propagation of sago palm has been conducted by other laboratories (Alang et al. 1991; Hisajima et al. 1991; Tahardi et al. 2002; Sumaryono et al. 2007). Moreover, somatic embryogenesis derived from callus has potential for producing an abundant supply of elite planting materials (Handley 1995; Riyadi et al. 2005; Sumaryono et al. 2012).

Unfortunately the somatic embryos obtained were heterogeneous with different size, colors and developmental stage (Kasi and Sumaryono 2006). Moreover, the in vitro propagation of sago palm has encountered some difficulties. Such difficulties are including weak, slow growing, low survival rate (Sumaryono et al. 2009) and browning on the tissue which end up with dying of explants. The purposes of our study were to solve the browning problem on explants and develop the propagation system of sago palm via in vitro culture through direct shoots derived from suckers as explants sources. Additionally to develop the base medium for initiation, multiplication, and elongation on sago palm with high survival rate when planting in the field. 


\section{MATERIALS AND METHODS}

\section{Plant materials and culture conditions}

Research activity was performed in Plant Tissue Culture Laboratory, Biotech Center which is located in PUSPIPTEK Area Serpong, South Tangerang, Banten. For the purpose of in vitro propagation, samples of sago suckers, as long as $7-10 \mathrm{~cm}$, were taken from Seram Island, Maluku Province. The sucker sterilization was conducted as described by Tajuddin et al. (2014). The culture conditions of sago palm in vitro propagation were shown in Table 1.

Table 1. Culture conditions

Medium:

- Basal component:

- MS (Murashige and Skoog 1962)

- B5 (Gamborg et al. 1976)

- Sugar: $30 \mathrm{~g} / \mathrm{L}$

- Solidifying Agent: $8 \mathrm{~g}$ agar/L

- $\mathrm{pH}: 5.8$ before autoclaving

- Volume: $10 \mathrm{~mL} / \mathrm{tube}$

\section{Culture Room:}

- Air temperature: $26 \pm 2^{\circ} \mathrm{C}$

- Light intensity: $1.500-2.000$ Lux

- Light source: cool-white fluorescent lamp 40 watt

- Photoperiod: 12 hours/day

\section{Preliminary experiment}

This experiment was accomplished in order to choose the initiation media for sago explants. In this experiment, the basic medium used was B5 with the addition of growth hormone combinations of BAP (Benzyl Amino Purine) (0.1 and $0.5 \mathrm{ppm}$ ) and NAA (Naphthalene Acetic Acid) (0.5 and $1.0 \mathrm{ppm}$ ). The first observation was carried out at 10 days after planting on the percentage of sterile culture. Then the subsequent observation was done every month on the growth response. The treatments repetition was 44 times.

\section{Multiplication media Experiment 1}

The purpose of this experiment was to obtain an optimal medium inducing the highest multiplication rate of sago shoots. The shoots grow directly from explant, which was from buds at the base of stem or from leaves, as adventitious shoots. There were two factors used as treatments for a low concentration of growth hormones combinations, i.e. growth hormone of cytokinin (BAP) at the concentration of $0,0.5,1.0$ and $2.0 \mathrm{ppm}$, and auxin (NAA) at the concentration of 0,1 and $2 \mathrm{ppm}$. The basic medium was B5, while the explants used were shoots derived from young suckers.

For a high concentration of growth hormone combinations, BAP concentrations were $3,5,10 \mathrm{ppm}$, whereas NAA were 3 and 4 $\mathrm{ppm}$. All treatments were repeated for 44 times. Observation was carried out for every four weeks on the percentage of culture growth, the growth of leaves, shoots initiation and the growth of plantlets.

\section{Experiment 2}

Similar to the first experiment, the purpose of this treatment was to obtain an optimal medium inducing for the highest multiplication rate of sago shoots. Two treatments were conducted on kinds of cytokinins, which were BAP and Kinetin. The concentrations of both growth hormones were 5 , $10,15,20,25$ and $30 \mathrm{ppm}$. The explants used were derived from preliminary experiment after culturing for 10 days. The explants were cut at the basal end in order to increase the surface layer which contact to the medium. Variables were observed on the fifth week after culture over the tissue response and development, changing of color and condition. All treatments were repeated for 7 times.

\section{Sub culturing}

Sub culturing was carried out in order to transfer the culture into a fresh media. The problem arose when explants were sub cultured into the media with the same composition. Most of sub cultured explants were browning and died. In order to reduce this problem, the experiment was conducted on the sub culture media. The purpose of the treatment was to decrease the auxin concentrations. In this experiment, the basic 
Table 2. Response of the growth hormone combination of BAP and NAA in producing shoots on sago explants after 12 weeks incubation

\begin{tabular}{lcc}
\hline $\begin{array}{l}\text { Hormone } \\
\text { Combination }\end{array}$ & $\begin{array}{c}\text { Explant with } \\
\text { Shoots }\end{array}$ & $\%$ Shoot \\
\hline BAP 0.1 - NAA 0.5 & $4 / 44$ & $9 \%$ \\
BAP 0.1 - NAA 1.0 & $9 / 44$ & $20 \%$ \\
BAP 0.5 - NAA 0.5 & $20 / 44$ & $45 \%$ \\
BAP 0.5 - NAA 1.0 & $21 / 44$ & $47 \%$ \\
\hline
\end{tabular}

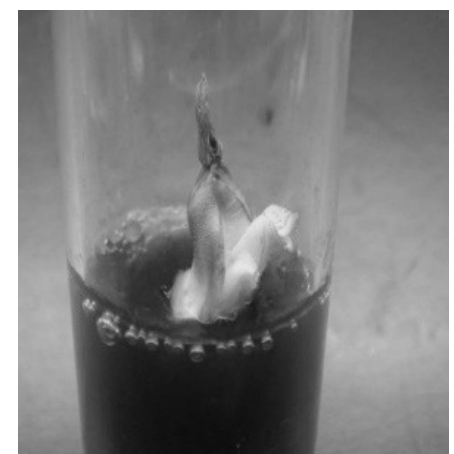

Figure 1. The sago explants development and producing shoot

media employed were MS, B5 and MS modified. The hormones used were NAA, IBA and IAA (Indole-3-Acetic Acid), with the concentration applied was 0.02 and $0.2 \mathrm{ppm}$, for each hormone. The explants utilized in this trial were derived from previous experiment. Some of the explants were already producing shoots. Observation was made on the number and percentage of survival explants, and their conditions (color and freshness). Treatment repetition was set for 5 times.

\section{RESULTS AND DISCUSSION}

\section{Preliminary experiment}

The purpose of the preliminary experiment was to estimate the amount of growth hormones required for sago culture in vitro. The culture media used was chosen that normally applied for palm trees, while the growth hormones are those for common used in tissue culture media and cheaper in prices, i.e. BAP and NAA. The results are displayed in Table 2. It showed that the combination of BAP $0.5 \mathrm{ppm}$ with NAA 0.5 or $1.0 \mathrm{ppm}$ gave higher percentage of shooting. On the other hand, the treatments of lower $\operatorname{BAP}(0.1 \mathrm{ppm})$
Table 3. The effect of multiplication medium with low concentration of hormones

\begin{tabular}{cccc}
\hline \multirow{2}{*}{$\begin{array}{c}\text { BAP } \\
(\mathrm{ppm})\end{array}$} & \multicolumn{3}{c}{ NAA (ppm) } \\
\cline { 2 - 4 } & 0 & 1 & 2 \\
\hline \multirow{2}{*}{0} & $18.2 \%$ & $4.5 \%$ & $15.9 \%$ \\
& $(8 / 44)$ & $(2 / 44)$ & $(7 / 44)$ \\
\multirow{2}{*}{0.5} & $27.3 \%$ & $9.1 \%$ & $31.8 \%$ \\
& $(12 / 44)$ & $(4 / 44)$ & $(14 / 44)$ \\
1.0 & $15.9 \%$ & $15.9 \%$ & $40.9 \%$ \\
& $(7 / 44)$ & $(7 / 44)$ & $(18 / 44)$ \\
2.0 & $29.5 \%$ & $18.1 \%$ & $40.9 \%$ \\
& $(13 / 44)$ & $(8 / 44)$ & $(18 / 44)$ \\
\hline
\end{tabular}

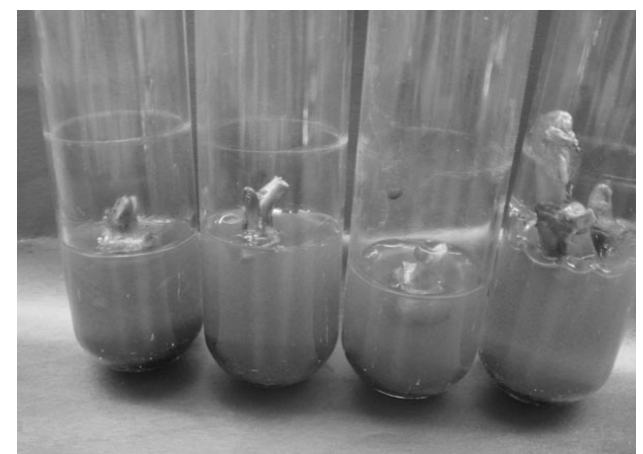

Figure 2. The shoots initiation on BAP $2 \mathrm{ppm}+$ NAA 2 ppm treatment

produced low percentage of shoot.

After 4 to 5 weeks of culture, the white tissue of explant was slowly changed in color into greenish red (Figure 1). Then the apical tissue was breaking and new shoots sprouted out from the inside after incubation for 6 to 8 weeks. Well developed shoot was being sub cultured into fresh media at 12 weeks of culture. This experiment revealed that the shoots were successfully induced on sago explants after more than 3 months in culture room.

\section{Multiplication media Experiment 1}

In the multiplication media, low concentration of growth hormones combination was used. The results of multiplication medium on the growth of shoots are exhibited in Table 3. The data were obtained after the culture was maintained for 3 month in the culture room. It showed that the treatment of BAP 1.0 or 2.0 ppm combined with NAA $2.0 \mathrm{ppm}$ produced the highest number of shoots (18 shoots or $40.9 \%$ ) compared to other treatments. The lowest number of shoots was found in the medium of BAP 0 ppm and NAA $1.0 \mathrm{ppm}$, which was 2 
Table 4. The effect of multiplication medium with higher concentration of hormones

\begin{tabular}{ccc}
\hline \multirow{2}{*}{$\begin{array}{c}\text { BAP } \\
(\mathrm{ppm})\end{array}$} & \multicolumn{2}{c}{$\mathrm{NAA}(\mathrm{ppm})$} \\
\cline { 2 - 3 } 3 & $11.4 \%(5 / 44)$ & $15.9 \%(7 / 44)$ \\
\hline 5 & $9.1 \%(4 / 44)$ & $9.1 \%(4 / 44)$ \\
10 & $4.5 \%(2 / 44)$ & $15.9 \%(7 / 44)$ \\
\hline
\end{tabular}

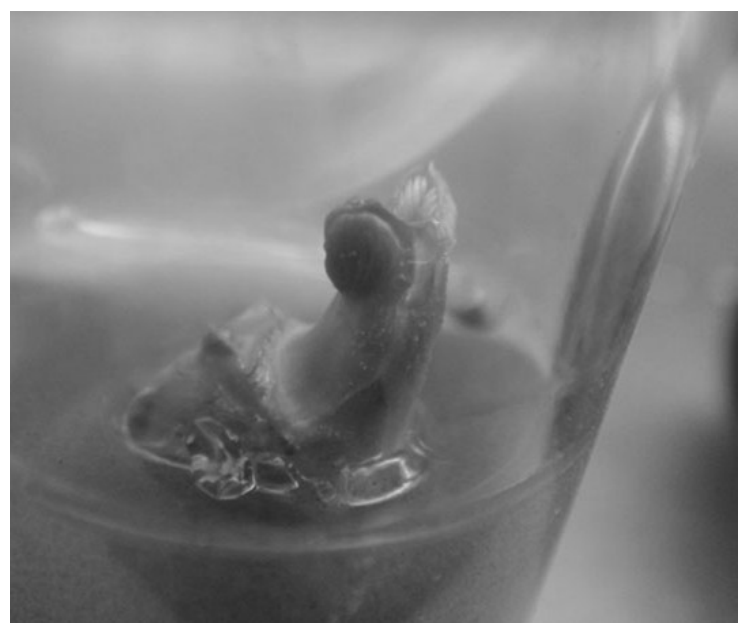

Figure 3. Shoot was developed on sago explants on BAP 3 ppm + NAA 4 ppm treatment

shoots or $4.5 \%$. It shows in Table 3 that the highest the concentration of hormone level, the highest the number of shoot obtained.

Figure 2 displays the shoot formation on sago explants after treated with BAP 2 ppm and NAA 2 ppm. The results obtained from this experiment had given an idea to increase the concentration of hormone level.

Higher concentration of growth hormone in the multiplication media also influenced the formation of shoots (Table 4). The experiment was conducted for six months. It needed more than 4 months for the culture to induce shoots (Figure 3 ). Nevertheless, the results demonstrated some variation on shoot number. There was no significant difference on the number of shoots. The treatment of BAP 3 ppm + NAA $4 \mathrm{ppm}$ has the same number of shoots with BAP 10 ppm + NAA 4 ppm. While at NAA 3 $\mathrm{ppm}$, increasing the concentration of BAP reduced the number of shoot drastically. It seems that higher concentration of BAP had
Table 5. Effect of higher concentration of growth hormones on sago explants after 3 months

\begin{tabular}{|c|c|c|c|}
\hline $\begin{array}{l}\text { Growth } \\
\text { Hormone }\end{array}$ & $\begin{array}{l}\text { Explant with } \\
\text { Shoot }\end{array}$ & $\begin{array}{c}\text { Explant } \\
\text { without Shoot }\end{array}$ & $\begin{array}{l}\text { Browning } \\
\text { and Died }\end{array}$ \\
\hline BAP5 & $57.1 \%(4 / 7)$ & $42.9 \%(3 / 7)$ & 0 \\
\hline BAP 10 & 0 & $42.9 \%(3 / 7)$ & $57.1 \%(4 / 7)$ \\
\hline BAP 15 & 0 & $28.6 \%(2 / 7)$ & $71.4 \%(5 / 7)$ \\
\hline BAP 20 & 0 & $28.6 \%(2 / 7)$ & $71.4 \%(5 / 7)$ \\
\hline BAP 25 & 0 & $14.3 \%(1 / 7)$ & $85.7 \%(6 / 7)$ \\
\hline BAP 30 & 0 & $14.3 \%(1 / 7)$ & $85.7 \%(6 / 7)$ \\
\hline Kinetin 5 & 0 & $100 \%(7 / 7)$ & 0 \\
\hline Kinetin 10 & 0 & $100 \%(7 / 7)$ & 0 \\
\hline Kinetin 15 & - & $100 \%(7 / 7)$ & - \\
\hline Kinetin 20 & - & $100 \%(7 / 7)$ & - \\
\hline Kinetin 25 & - & - & $100 \%(7 / 7)$ \\
\hline Kinetin 30 & - & $14.3 \%(1 / 7)$ & $85.7 \%(6 / 7)$ \\
\hline
\end{tabular}

negative effect to the number of shoots of sago.

\section{Experiment 2}

High concentration of cytokinins (BAP and Kinetin), were used for shoots induction on sago explants. The consequence of high concentration of growth hormone however may increase the vitrification on some kind of plants, especially horticulture plants (Yusnita 2004), so the color of explants can be changed to transparantly white. Nevertheless, such a case was not appeared to sago explants in our study. They did not show any vitrification under higher level of growth hormones. The results were showed in Table 5 below. It revealed that treatment of BAP 5 ppm gave rise to better results. From 7 explants treated with BAP $5 \mathrm{ppm}, 4$ explants showed positive response. It has swollen structure at the basal end, with many small shoot-like structure emerged from inside. 


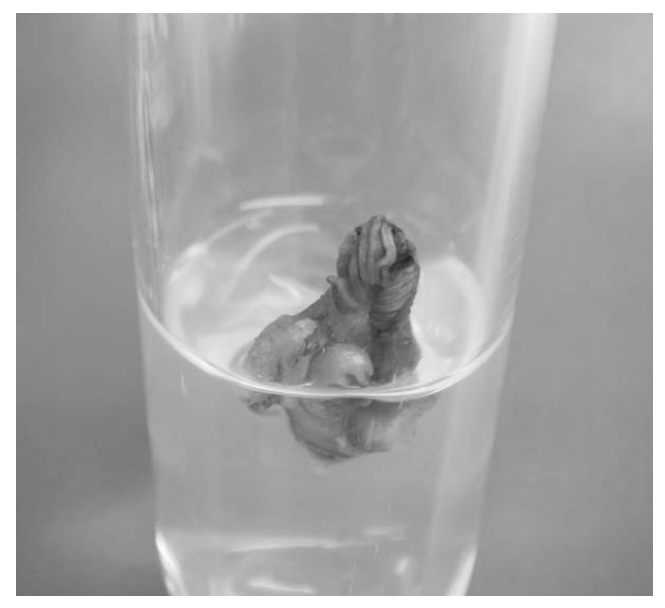

Figure 4. Positive response on explants induced with BAP 5 ppm

Since the experiment was still 3 months old, it may need more time to see whether these structures may transform to shoot or other organs. On other treatments, there were no significant responses confirmed, and some of the explants turn to yellowish brown in color and then died.

These results verified that BAP at the concentration of $5 \mathrm{ppm}$ induced shoots and maintained the freshness of explants (Figure 4). Another finding showed that different explants on BAP $5 \mathrm{ppm}$ treatment exhibited different structures. Their responses probably depend on physiological or autogenetic property of the explants (Yusnita 2004), as it may develop into callus, rooting or multiplication shoots as expected. Above that concentration (BAP 10 ppm or over), the explants became brownish in color and died. For the growth hormone of kinetin, up to the concentration of $20 \mathrm{ppm}$, it still maintained the freshness of the explants during 3 months of incubation; even no shoot initiation was obtained. Above that concentration, it displayed that the explants changed to yellowish brown in color, dried and died.

\section{Sub culturing}

After culturing the explants in the tube and keeping it in culture room for 2 to 3 months, the medium used would be dried out, and all of the nutrition inside the medium would be absorbed by cell or tissue. In such case, the explants should be transferred into new media to maintain the growth with full support for nutrition. This process in plant tissue culture is known as sub culture. For sago explants, the problems arise after sub culturing. Almost all explants or shoots become yellowing in color

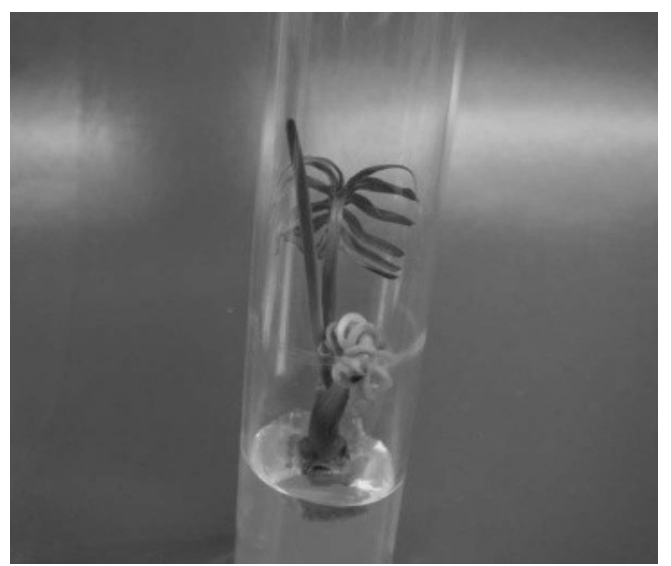

Figure 5. Sago shoots freshness were maintained after sub culturing into media with lowering auxin concentration

and died after sub culturing was completed into the media with the same composition. It subsequently revealed that it should be transferred into media with lowering auxin concentration.

In this experiment, three kinds of auxin (NAA, IBA and IAA) with concentration of 0.02 and $0.2 \mathrm{ppm}$ were added into three different basic media (MS, B5 and the modified MS). It showed that all treatments gave the same outcome. The percentage of shoots reached $100 \%$ for all parameters (the results not shown). The growth of shoots could be maintained steadily up to the end of experiment period (for 6 months) with fresh tissues and green in color (Figure 5). This confirms that lowering the auxin content is better for sub culturing the sago shoots, regardless of kinds of media used previously. Since the B5 medium had already been used for initiation and multiplication, hence for sub culturing the B5 medium was also used.

\section{CONCLUSION}

From our research activities it can be concluded that the number of shoots tends to increase with increasing the concentration of growth hormone cytokinins up to middle level. The combination of BAP $0.5 \mathrm{ppm}$ with NAA 0.5 and $1.0 \mathrm{ppm}$ resulted in higher percentage of shoot. The combination of growth hormone BAP $2 \mathrm{ppm}$ and NAA $2 \mathrm{ppm}$ produced the highest number of shoots (18 shoots or $40.9 \%$ ). Conversely, at higher concentration of hormone in multiplication medium, increasing the concentration of BAP had negative effect, which reduced the number of shoots and turned the 
explants to browning, and then died. While BAP $5 \mathrm{ppm}$ induced shoots and maintained the freshness of explants. Almost all explants or shoots become yellowing in color and died after the sub culturing was done into fresh media with the same composition. Lowering the auxin content is better for sub culturing the sago shoots, regardless of kinds of media used before.

\section{ACKNOWLEDGMENTS}

This work was supported by research collaboration between PT Sampoerna Bio Energi and Biotech Center BPPT on the Establishment of Tissue Culture System of Sago Palm.

\section{REFERENCES}

Alang ZC, Krishnapillay B, Pilus SF, Hisajima S (1991) Embryo culture and nursery establishment of sago palm (Metroxy-lon spp.) plantlets. Proceedings of the Fourth International Sago Symposium, August 6-9, 1990, Kuching, Serawak, Malaysia

Flach M (1997) Sago Palm, Metroxylon sagu Rottb. Promoting the Conservation and use of Underutilized and Neglected Crops, 13. International Plant Genetic Resource Institute (IPGRI) Italy and IPK Germany, 71pp

Gamborg OL, Murashige T, Thorpe TA, Vasil IK (1976) Plant tissue cultura media. In Vitro 12:473-478

Handley LW (1995) Future uses of somatic embryogenesis in woody plantation species. In:S. Jain (ed) Somatic Embryogenesis in Woody Plants Vol 1:415-434

Hisajima S, Jong FS, Arai Y, Sim ES (1991) Propagation and breeding of sago palm (Metroxylon sagu Rottb.) plant in vitro:1. Embryo culture and induction of multiple shoots from sago embryos in vitro. Jap J Trop Agric 35:259-267

Jong FS (1995) Research for the development of sago palm (Metroxylon sagu Rottb.) cultivation in Sarawak, Malaysia. PhD Thesis, Wageningen University 139pp.

Kasi PD, Sumaryono (2006) Keragaman morfologi selama perkembangan embrio somatik sagu (Metroxylon sagu Rottb). Menara Perkebunan 74:44-52

Miftahorrachman, Novarianto H (2003) Jenisjenis sagu potensial di Sentani Irian Jaya.
Dalam Prosiding Seminar Ketahanan Pangan. Manado 6 Oktober 2003

Murashige T, Skoog F (1962) A revised medium for rapid growth and bioassays with tobacco tissue cultures. Physiol Plant 15:473-497

Okazaki M, Tadenuma S, Ohmi M (2005) Diverse utilization and industrial development of sago biomass. Proceeding Abstract $p$ 2. In YP Karafir, VE Fere and $Y$ Toyoda (Eds). The Eight International Sago Symposium, August 4-6, 2005, Manokwari. The Japan Society for Promotion of Science

Riyadi I, Tahardi JS, Sumaryono (2005) The development of somatic embryos of sago palm (Metroxylon sagu Rottb) on solid media. Menara Perkebunan 73:35-43

Setyabudi A, Widyaningtyas N (2008) Sagu (Metroxylon spp.) sebagai Sumber Energi Bioetanol Potensial. Badan Penelitian dan Pengembangan Kehutanan Departemen Kehutanan

Sumaryono, Riyadi I, Kasi PD (2007) Perbanyakan klonal tanaman sagu unggul melalui kultur jaringan. Prosiding Lokakarya Pengembangan Sagu di Indonesia. Pusat Litbang Perkebunan, Batam 25-26 Juli 2007

Sumaryono, Riyadi I, Kasi PD (2009) Clonal propagation of sago palm (Metroxylon sagu Rottb) through tissue culture. J Appl Ind Biotechnol Trop Reg 2:1-4

Sumaryono, Muslihatin W, Ratnadewi D (2012) Effect of carbohydrate source on growth and performance of in vitro sago palm (Metroxylon sagu Rottb) plantlets. Hayati J Biosci 19:88-92

Tahardi JS, Sianipar NF, Riyadi I (2002) Somatic embryogenesis in sago palm (Metroxylon sagu Rottb.). In: $\mathrm{K}$ Kaimuna, M Okazaki, Y Toyoda, JE Cecil (eds) New Frontiers of Sago Palm Studies p75-81. Universal Academic Press, Inc. Tokyo, Japan

Tajuddin T, Karyanti, Sukarnih T, Haska N (2014) A revised method for sago palm (Metroxylon sagu Rottb.) sucker explants sterilization to support the in vitro propagation. J Bioteknol Biosains Indones 1:21-26

Yusnita (2004) Kultur Jaringan Cara Memperbanyak Tanaman secara Efisien. Agromedia Pustaka. Jakarta 